\title{
Fruiting of fleshy-fruited plants and abundance of frugivorous birds: Phenological correspondence in a temperate forest in central Japan
}

\author{
Yoichiro TAKANOSE ${ }^{1, \#}$ and Tomohiko KAMITANI ${ }^{2}$ \\ ${ }^{1}$ Graduate School of Science and Technology, Niigata University, Niigata 950-2181, Japan \\ ${ }^{2}$ Faculty of Agriculture, Niigata University, Niigata 950-2181, Japan
}

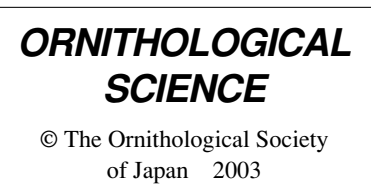

\begin{abstract}
We investigated the seasonal correspondence between the fruiting phenology of fleshy-fruited plants and the abundance of frugivorous birds, in a temperate forest, in central Japan. The majority of fleshy fruits ripened in the fall when frugivorous birds were most abundant. This correspondence occurred earlier than in a warm temperate forest, located in southern Japan; these relationships in East Asia coincide with those of the temperate regions of North America and Europe. We also examined whether the abundance of frugivorous birds led to profitable effects for seed dispersal among fleshy-fruited plants. The Brown-eared Bulbul Hypsipetes amaurotis was considered to be an important seed disperser for many fleshy-fruited plants because of its high frequency of occurrence throughout the fruiting season, and its large gape size, which allowed it to swallow all sizes of fruits found at the study site. Although numerous Brown-eared Bulbuls and other frugivorous birds were present in the fall, fruit removal rates in fall-fruiting species were not always higher than in summerfruiting species. The abundance of frugivorous birds alone could therefore not adequately explain the concentrated fruiting phenology among fleshy-fruited plants.
\end{abstract}

Key words Fleshy-fruited plant, Frugivorous bird, Fruit removal rate, Fruiting phenology

The relationship between the fruiting phenology of fleshy-fruited plants and their dispersal agents has been described at the community level in various regions (e.g., Thompson \& Willson 1979; Stiles 1980; Sorensen 1981; Herrera 1984; Izhaki \& Safriel 1985; Skeate 1987; Loiselle \& Blake 1991; Debussche \& Isenmann 1992; French 1992; Noma \& Yumoto 1997). Fruiting periods that correspond to seasonal variation in the abundance of dispersal agents have been identified as one of the characteristic events of temperate regions. In North America, this correspondence has been examined in different climatic regions. The fruiting periods of many fleshy-fruited plants in cool temperate forests are generally concentrated in the fall, when a large number of frugivorous birds migrate south (Thompson \& Willson 1979; Stiles 1980; Stapanian 1982). Fruiting periods in a warm southern temperate forest, however, were post-

(Received 9 September 2002; Accepted 29 October 2002)

\# Corresponding author, E-mail: f98t868g@mail.cc.niigata-u.ac.jp poned to the winter, when large populations of frugivorous birds arrived to overwinter (Skeate 1987). Similar relationships have also been reported in Europe (Herrera 1984), and variations in the dates of maximum fruit availability among communities situated along latitudinal gradients coincide with those of maximum abundance of frugivorous birds (Fuentes 1992). In East Asia, Noma and Yumoto (1997) found a close correspondence between the fruiting periods of many fleshy-fruited plants and the fluctuation of frugivorous birds in a warm temperate forest, in southern Japan. This correspondence was similar to previous reports from lower latitudes in North America and Europe, however, no detailed comparison with other regions has been conducted in East Asia.

We examined the possibility that efficient seed dispersal may cause the fruiting period of a fleshyfruited plant to coincide with the fall migration and overwintering of many frugivorous birds. Abundant dispersal agents may cause higher rates of fruit removal and constitute, therefore, a selective influence 
on the fruiting phenology of fleshy-fruited plants. Contrary to this hypothesis, however, not all species, whose fruits ripen when frugivorous birds are plentiful, show evidence of higher fruit removal rates. In fleshy-fruited plants that have low quality fruits, the fruits persist on the trees for a long time and are dispersed less efficiently (Stiles 1980; Kominami 1987).

The objective of our research was to examine the correspondence between the fruiting periods of various fleshy-fruited plants and seasonal variation in the abundance of frugivorous birds in a temperate forest, in central Japan. In particular, it was thought that a comparison with the findings from a warm temperate forest in southern Japan (Noma \& Yumoto 1997) would help to explain the mechanisms of seed dispersal by frugivorous birds in East Asia from a phenological point of view. We also examined whether frugivorous birds present during the fruiting periods of fleshy-fruited plants would have a large gape size enough to swallow fruits whole. Frugivorous birds with a small gape can swallow only small fruits, while those with a large one can swallow fruits of various sizes (Wheelwright 1985; Noma \& Yumoto 1997). Finally, we tested the hypothesis that fruiting during a period when frugivorous birds are most abundant leads to stable and higher fruit removal. We also discuss profitable fruiting periods for seed dispersal among fleshy-fruited plants.

\section{METHODS}

\section{1) Study site}

The study site was located at the foot of Mt. Kakuda (482 m) in Niigata Prefecture, central Japan $\left(37^{\circ} 46^{\prime} \mathrm{N}, 138^{\circ} 50^{\prime} \mathrm{E}\right)$. According to the Niigata Meteorological Observatory, the mean annual temperature and precipitation are $13.5^{\circ} \mathrm{C}$ and $1,776 \mathrm{~mm}$, respectively. The elevation is approximately $100 \mathrm{~m}$ a.s.l. The major canopy species are Quercus serrata and Pinus densiflora, whereas the shrub layer is composed mainly of Eurya japonica, Viburnum dilatatum, and Aucuba japonica var. borealis. Both cool and warm temperate forest species are found at the study site.

\section{2) Frugivorous birds}

The population and species composition of birds were recorded by the line-census method from May 1995 to April 1997. A census route approximately $1.5 \mathrm{~km}$ long was established along a path through the study site. We walked along the census route for three hours just after sunrise and recorded all birds observed within $25 \mathrm{~m}$ of both sides of the line. The census was usually conducted once a week, but in the fall, when bird abundance fluctuated dramatically, it was conducted three times a week. Due to inclement weather, the frequency of observations was reduced in the winter. The literature (Kiyosu 1978) and direct observations served to establish whether observed bird species were frugivorous (see Appendix 1).

\section{3) Fleshy-fruited plants}

We monitored the flowering and fruiting phenology of 51 woody plant species that bore fleshy fruits (see Appendix 2). During the same period that birds were censused, five individual plants of each species were tagged along the census route, and their phenological traits, such as flowering, fruiting, and fruit disappearance, were recorded once a week. The flowering and fruiting periods of each species were defined in terms of the number of days from the first flowering and fruiting to the disappearance of all flowers and fruits on the tagged plants. From these observations of fruiting phenology, the 51 species were classified into three fruiting types; summer-, fall-, or spring-fruiting species (see Appendix 2).

Fruit removal from the six principal species of each fruiting type was examined for three consecutive years from 1996 to 1998. Broussonetia kazinoki (Moraceae), Prunus apetala ssp. pilosa (Rosaceae), and Sambucus racemosa ssp. sieboldiana (Caprifoliaceae) were summer-fruiting species and Eurya japonica (Theaceae), Viburnum dilatatum, and $V$. wrightii (Caprifoliaceae) were fall-fruiting species. Fruit removal rates were examined in the following two ways. In 1996, four to 12 individuals of each species were randomly selected and their fruits were counted once or twice every two weeks under natural conditions. We also selected several individuals from each species and covered their inflorescences with nylon nets to eliminate fruit consumption by birds. Fruits that dropped off naturally were caught within the nets and counted. The difference between the number of fruits that disappeared under natural conditions and the numbers on the netted plants was regarded as the number of fruits removed by birds. In 1997 and 1998, we again selected three to five individuals of the same plant species and set up seed traps underneath them. The number of fruits on the plants and the number of fruits that fell into the seed traps were recorded once or twice every two weeks. The difference between the two fruit counts was con- 
sidered to be the number of fruits removed by birds.

We measured the size of 30 fruits selected randomly from the sample species. Gape sizes of frugivorous birds were recorded from the literature (Noma \& Yumoto 1997).

\section{4) Data analysis}

Seasonal differences in the mean number of frugivorous bird species counted in each census were analyzed using Tamhane's multiple comparison, and differences in the mean species numbers were tested by season using Bonferroni's multiple comparison. The relationship between frugivorous bird abundance and the number of fleshy-fruited plant species with ripe fruits was investigated using Kendall's rank correlation test. For the above analyses, census data from two consecutive years were combined. Fruit removal rates in summer-fruiting species were compared using a t-test to detect any differences between study years, whereas removal rates in fall-fruiting species were tested with a Kruskal-Wallis test.

\section{RESULTS}

1) Seasonal variation in the abundance of frugivorous birds

Of the 63 bird species that we observed during the monitoring periods, 24 were frugivorous. Of these frugivorous species, nine were residents while the other 15 were migrants. The population of frugivorous birds was stable throughout the summer months (Fig. 1). Brown-eared Bulbuls Hypsipetes amaurotis were observed most frequently, while the second most observed species was the Japanese White-eyes Zosterops japonicus. These two species accounted for $>80 \%$ of the total population of frugivorous birds recorded during the summer. The population of frugivorous birds increased rapidly in the early fall. The first peak in numbers occurred in mid-September in 1995, and in early October in 1996, and this peak was due mainly to the increase of Japanese White-eyes (Fig. 2). The second peak in both study years occurred around late October, when migratory winter birds such as Dusky Thrushes Turdus naumanni and Pale Thrushes $T$. pallidus began to reach the study site (Fig. 2). The Brown-eared Bulbul was observed frequently from September to November (Fig. 2). The total population of the Brown-eared Bulbul and the Japanese White-eye reached over $70 \%$ of the total population of frugivorous birds recorded during the fall. The mean number of frugivorous birds counted during each census was higher in the fall than in the other seasons (Fig. 3). The population of frugivorous birds decreased in December and remained low
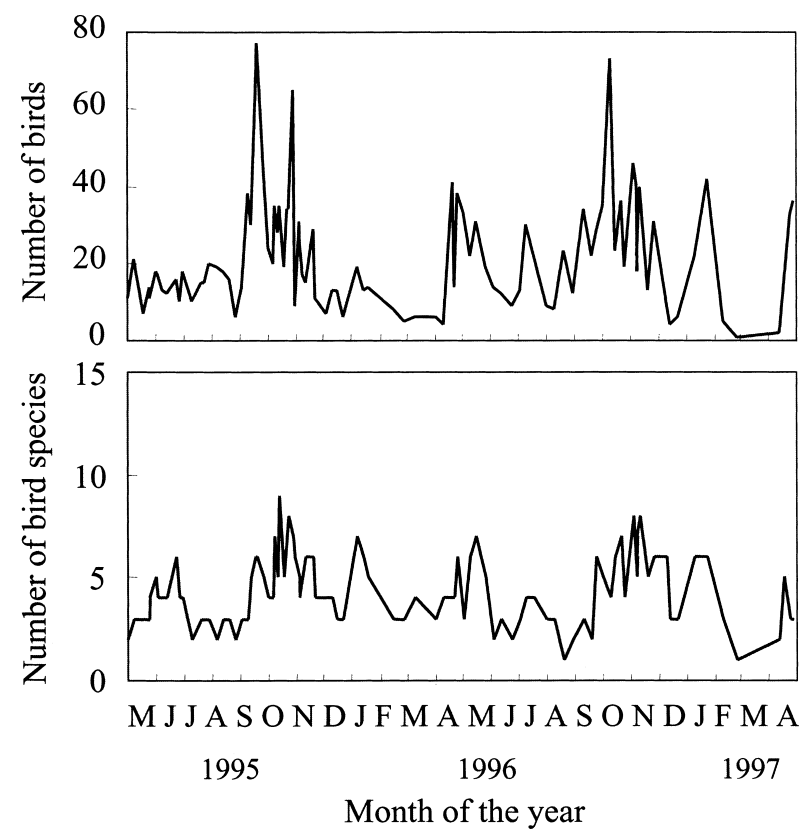

Fig. 1. Seasonal variation in the number of individuals and species of frugivorous birds recorded along a census route between May 1995 and April 1997.

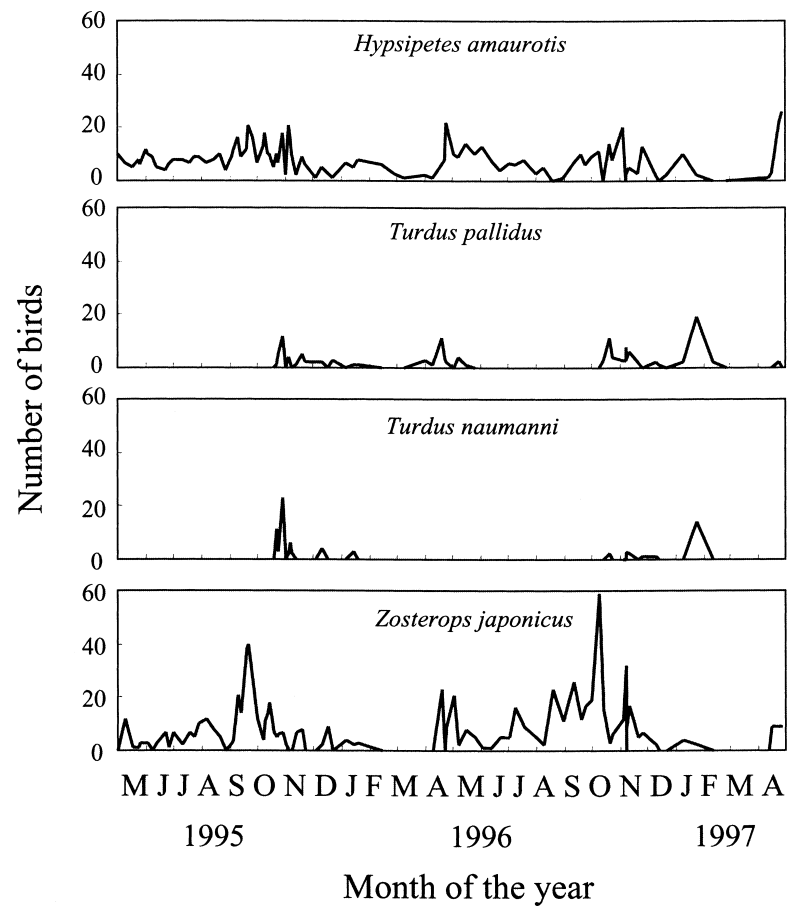

Fig. 2. Seasonal variation in the number of individuals of the principal frugivorous birds recorded along a census route between May 1995 and April 1997. 

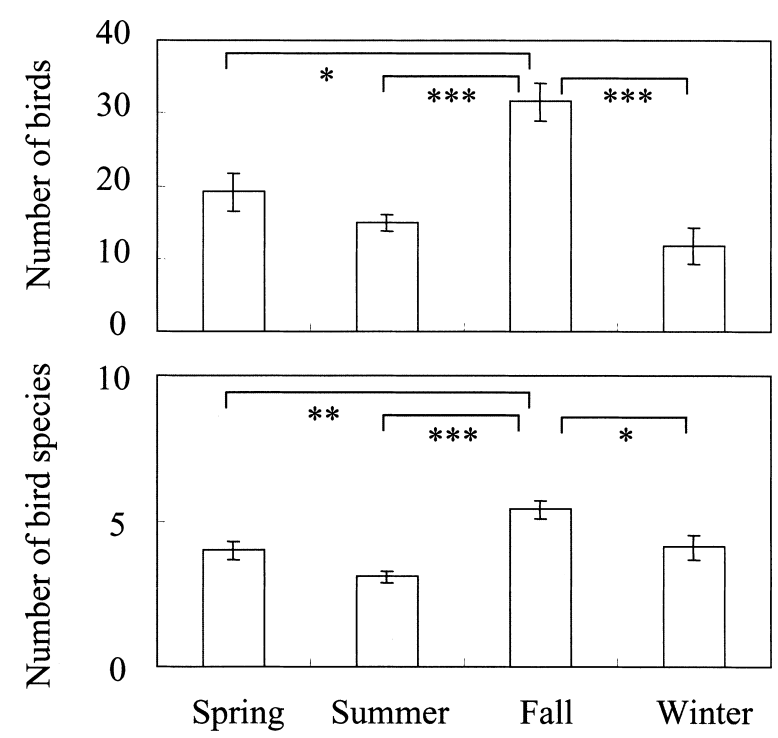

Fig. 3. Seasonal differences in the mean number of individuals and species of frugivorous birds recorded during each census $( \pm \mathrm{SE})$. The combined census data for two consecutive years were divided into four categories: Spring (March-May), Summer (June-August), Fall (September-November), Winter (December-February). The number of individuals and species of birds were compared between the categories using Tamhane's and Bonferroni's multiple comparison test, respectively. $* \mathrm{P}<0.05 ; * * \mathrm{P}<0.01 ; * * * \mathrm{P}<0.001$.

throughout the winter months. One notable exception was a large flock of Dusky and Pale Thrushes observed in the study site in late January 1997. In mid April, the number of birds began to increase again. The dominant species were the Brown-eared Bulbul and the Japanese White-eye, which accounted for $78 \%$ of the total population of frugivorous birds observed during the spring. Seasonal variation in the number of frugivorous bird species showed a similar pattern to that of individuals (Fig. 1). The mean number of species of frugivorous birds counted during each census was higher in the fall than in the other seasons (Fig. 3).

2) Phenology of fleshy-fruited plants

The flowering periods of fleshy-fruited plants were concentrated in the period from May to July, and fruiting periods also showed a notable seasonality (Fig. 4). The number of fleshy-fruited plant species with ripe fruits fluctuated slightly during the summer, however, it increased rapidly in early September and reached a peak during late October and mid-November (Fig. 4). Thereafter, the number of fruiting species decreased gradually in late November and re-
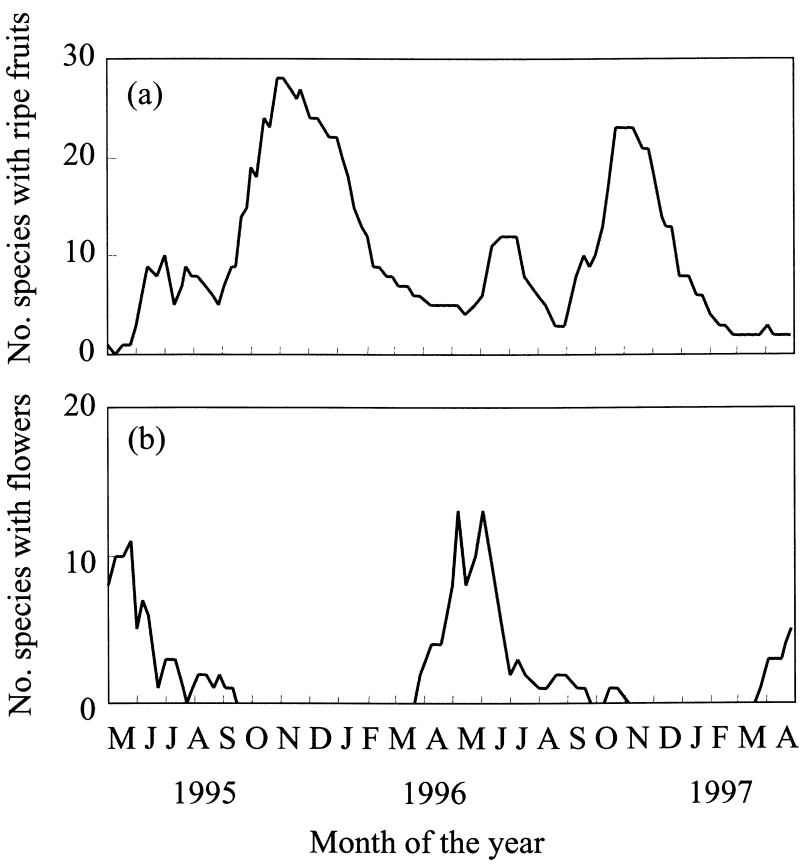

Fig. 4. Seasonal variation in the number of fleshy-fruited plant species that bore ripe fruits (a) and flowers (b) between May 1995 and April 1997.

mained low from late winter to spring. We found that the number of fruiting species and the number of frugivorous birds were significantly correlated (Kendall's rank correlation test, $\tau=0.19, \mathrm{~N}=75, \mathrm{P}=$ $0.02)$; numbers of bird species were also correlated to the number of fruiting species $(\tau=0.39, \mathrm{~N}=75$, $\mathrm{P}=0.00$ ).

Of the 51 plant species investigated, 18 were defined as summer-fruiting species. Fruits of the summer-fruiting species ripened soon after flowering, and almost all such fruits disappeared before the fall. Fruits of several species (Prunus apetala ssp. pilosa, Rubus palmatus var. coptophyllus, and R. hirsutus) began to ripen around late May. Fruits of the 32 fallfruiting species ripened from September to November, when frugivorous birds were abundant. More than $60 \%$ of the fleshy-fruited plant species in the study site belonged to this fruiting type. Several species maintained intact fruits during midwinter. The only spring-fruiting species was Aucuba japonica var. borealis. Although most fleshy-fruited plants produced fruits in the fall or summer, a few fruits of A. japonica var. borealis began to ripen in late November, as the abundance of frugivorous birds decreased gradually. The majority of the fruits ripened in late March, and almost all fruits had disappeared 
Table 1. Fruit removal rates in six fleshy-fruited plant species.

\begin{tabular}{|c|c|c|c|c|}
\hline & 1996 & 1997 & 1998 & $\mathrm{P}$ \\
\hline \multicolumn{5}{|l|}{ Summer-fruiting species } \\
\hline Prunus apetala ssp. pilosa & $\begin{array}{c}85.5 \pm 3.7 \\
(\mathrm{~N}=10)\end{array}$ & $\begin{array}{c}65.0 \pm 13.4 \\
(\mathrm{~N}=5)\end{array}$ & $\cdots$ & NS \\
\hline Sambucus racemosa ssp. sieboldiana & $\begin{array}{c}81.5 \pm 7.3 \\
(\mathrm{~N}=6)\end{array}$ & $\begin{array}{c}76.7 \pm 7.5 \\
(\mathrm{~N}=5)\end{array}$ & $\cdots$ & NS \\
\hline Broussonetia kazinoki & $\begin{array}{c}32.1 \pm 5.6 \\
(N=12)\end{array}$ & $\begin{array}{c}31.1 \pm 11.4 \\
(\mathrm{~N}=5)\end{array}$ & $\cdots$ & NS \\
\hline \multicolumn{5}{|l|}{ Fall-fruiting species } \\
\hline Eurya japonica & $\begin{array}{c}75.8 \pm 10.6 \\
(\mathrm{~N}=10)\end{array}$ & $\begin{array}{c}16.4 \pm 10.0 \\
(\mathrm{~N}=4)\end{array}$ & $\begin{array}{c}71.4 \pm 8.8 \\
(\mathrm{~N}=5)\end{array}$ & $<0.05$ \\
\hline Viburnum dilatatum & $\begin{array}{c}63.9 \pm 6.1 \\
(\mathrm{~N}=9)\end{array}$ & $\begin{array}{c}19.2 \pm 9.9 \\
(\mathrm{~N}=4)\end{array}$ & $\begin{array}{c}20.1 \pm 8.5 \\
(\mathrm{~N}=5)\end{array}$ & $<0.01$ \\
\hline V. wrightii & $\begin{array}{c}49.9 \pm 18.0 \\
(\mathrm{~N}=4)\end{array}$ & $\begin{array}{c}32.8 \pm 3.4 \\
(\mathrm{~N}=3)\end{array}$ & $\begin{array}{c}31.4 \pm 2.5 \\
(\mathrm{~N}=5)\end{array}$ & NS \\
\hline
\end{tabular}

1 Figures are means \pm SE.

${ }^{2}$ Fruit removal rates of the summer- and fall-fruiting species were compared with a t-test and a Kruskal-Wallis test, respectively.

${ }^{3} \mathrm{NS}=$ no significant difference $(\mathrm{P}>0.05) ; \cdots=$ no observations.

prior to fruit production of the summer-fruiting species.

3) Fruit removal by frugivorous birds

Mean fruit sizes of the summer- and fall-fruiting species were $8.4 \pm 2.1 \mathrm{~mm}(\mathrm{~N}=11)$ and $5.9 \pm 1.8 \mathrm{~mm}$ $(\mathrm{N}=26)$, respectively. The gape size of the Browneared Bulbul, which was the frugivorous bird most often observed in summer and the second most often observed in fall, is $13.3 \mathrm{~mm}$ (Noma \& Yumoto 1997), i.e. large enough to swallow the fruits of both fruiting types whole. The gape size of the Japanese Whiteeye, the second most frequently observed frugivore in summer, and the most frequent in fall, is $6.1 \mathrm{~mm}$ (Noma \& Yumoto 1997), which is only large enough to swallow the smaller fruits of both fruiting types.

We found no significant differences in fruit removal rates among summer-fruiting species $(B$. kazinoki, $P$. apetala ssp. pilosa, and $S$. racemosa ssp. sieboldiana) between the study years (Table 1). Not all fruits were removed to the same degree by frugivorous birds. P. apetala ssp. pilosa and S. racemosa ssp. sieboldiana experienced high fruit removal rates (65-86\%), whereas those of B. kazinoki were low $(31-32 \%)$ in both years. In contrast, the fall-fruiting species showed different tendencies over the study years (Table 1). Fruit removal rates in E. japonica and $V$. dilatatum were significantly different over three consecutive years, and fluctuated widely from
16 to $76 \%$. The fruits of $V$. wrightii were consistently removed in three consecutive years. No conspicuous differences in fruit removal rates were noticed between summer- and fall-fruiting species.

\section{DISCUSSION}

The fruits of more than $60 \%$ of fleshy-fruited plants in a temperate forest in central Japan ripened in the fall, when frugivorous birds were most abundant. Noma and Yumoto (1997) found a similar correspondence during the winter in a warm temperate forest in southern Japan. These findings in latitudinally diverse regions, imply a phenological correspondence during different seasons in East Asia, a correspondence that is similar to phenomena that have been reported in North America (Thompson \& Willson 1979; Skeate 1987) and Europe (Fuentes 1992).

We attempted to explain these phenological correspondences by focusing on several key seed dispersers and fleshy-fruited plants. The Brown-eared Bulbul and the Japanese White-eye are probably the main seed dispersers, as they account for $44-86 \%$ of the total population of frugivorous birds during each season. The increased population of frugivorous birds recorded in the fall can be attributed to migratory flocks of Brown-eared Bulbuls and Japanese Whiteeyes that breed further north. In a warm temperate 
forest, in southern Japan, the winter expansion of the frugivorous bird population is primarily due to the migration of wintering populations of these two bird species (Noma \& Yumoto 1997). This suggests that regardless of latitude, many fleshy-fruited plants may depend on particular bird species, such as the Browneared Bulbul and the Japanese White-eye, for seed dispersal. Moreover, the bulbul is a very important dispersal agent qualitatively because its gape is large enough to easily swallow fruits of various sizes. Fukui (1995) found that the Brown-eared Bulbul consumed fruits of 53 species from 24 plant families. The Japanese White-eye is probably a major seed disperser for plants that bear smaller fruits. Large thrushes, such as the Dusky Thrush and the Pale Thrush, are also important bird species that are usually observed around late October at the study site. Although populations of these thrushes are not as large as those of the Brown-eared Bulbul or the Japanese White-eye, they contribute to seed dispersal due to their timely arrival and large gape size (>10.0 mm; Karasawa 1978). Kominami (1987) inferred that the Dusky Thrush contributed much to fruit removal in $V$. dilatatum in a cool temperate forest, in northern Japan, despite the presence of other dominant species such as the Brown-eared Bulbul.

We investigated whether fruit removal was profitable in the fall when frugivorous birds were most abundant at our study site. Fruit removal rates from fleshy-fruited European plants that ripen during the migratory seasons of frugivorous birds exceeded $80 \%$ (Jordano 1982; Herrera 1984), which might attest to the effect of frugivorous bird abundance on seed dispersal. High fruit removal rates at our study site were recorded in two summer-fruiting species, $P$. apetala ssp. pilosa and $S$. racemosa ssp. sieboldiana, rather than in fall-fruiting species. Fruit removal rates in the fall-fruiting species differed greatly among species and study years. Such instability may be caused by keener competition among plant species for seed dispersers due to the concentrated fruiting of fleshyfruited plants in the fall. The peculiar position of $A$. japonica var. borealis, which was the only springfruiting species, is very interesting in our phenological study. A few frugivorous bird species, such as the Brown-eared Bulbul, were comparatively abundant in the spring, whereas fleshy-fruited plant species with ripe fruit were scarce. The spring fruiting of A. japonica var. borealis may therefore be a phenological strategy to escape interspecific competition.

Thus, fruiting in the fall when frugivorous birds are most abundant would not necessarily lead to profitable dispersal. Our results imply that the fruits of fleshy-fruited plants are likely to be removed efficiently during each fruiting season. A long-term and continuous study (e.g., Herrera 1998) will be required to further explain the phenological correspondence between fleshy-fruited plants and the abundance of frugivorous birds in temperate regions.

\section{ACKNOWLEDGMENTS}

We are grateful to K. Takahashi for his valuable suggestions, in relation to our research, and we thank graduate students of Niigata University for their helpful assistance during the study. This study was partly supported by a grant from the Ministry of Education, Science and Culture of Japan (no. 14608022).

\section{REFERENCES}

Debussche M \& Isenmann P (1992) A mediterranean bird disperser assemblage: composition and phenology in relation to fruit availability. Rev Ecol (Terre Vie) 47: 411-432.

French K (1992) Phenology of fleshy fruits in a wet sclerophyll forest in southeastern Australia: are birds an important influence? Oecologia 90: 366-373.

Fuentes M (1992) Latitudinal and elevational variation in fruiting phenology among western European birddispersed plants. Ecography 15: 177-183.

Fukui AW (1995) The role of the brown-eared bulbul Hypsypetes amaurotis as a seed dispersal agent. Res Popul Ecol 37: 211-218.

Herrera CM (1984) A study of avian frugivores, birddispersed plants, and their interaction in Mediterranean scrublands. Ecol Monogr 54: 1-23.

Herrera CM (1998) Long-term dynamics of Mediterranean frugivorous birds and fleshy fruits: a 12-year study. Ecol Monogr 68: 511-538.

Izhaki I \& Safriel UN (1985) Why do fleshy-fruit plants of the mediterranean scrub intercept fall- but not spring-passage of seed-dispersing migratory birds? Oecologia 67: 40-43.

Jordano P (1982) Migrant birds are the main seed dispersers of blackberries in southern Spain. Oikos 38: 183-193.

Karasawa K (1978) Relationships between fruit-eating birds and seed dispersal in urbanized areas. Tori 27: 1-20 (in Japanese).

Kiyosu Y (1978) The birds of Japan. Kodansha, Tokyo (in Japanese).

Kominami Y (1987) Removal of Viburnum dilatatum 
fruit by avian frugivores. Ecol Rev 21: 101-106.

Loiselle BA \& Blake JG (1991) Temporal variation in birds and fruits along an elevational gradient in Costa Rica. Ecology 72: 180-193.

Noma N \& Yumoto T (1997) Fruiting phenology of animal-dispersed plants in response to winter migration of frugivores in a warm temperate forest on Yakushima Island, Japan. Ecol Res 12: 119-129.

Skeate ST (1987) Interactions between birds and fruits in a northern Florida hammock community. Ecology 68: 297-309.

Sorensen AE (1981) Interactions between birds and fruit in a temperate woodland. Oecologia 50: 242-249.

Stapanian MA (1982) Evolution of fruiting strategies among fleshy-fruited plant species of eastern Kansas. Ecology 63: 1422-1431.

Stiles EW (1980) Patterns of fruit presentation and seed dispersal in bird-disseminated woody plants in the eastern deciduous forest. Am Nat 116: 670-688.

Thompson JN \& Willson MF (1979) Evolution of temperate fruit/bird interactions: phenological strategies. Evolution 33: 973-982.

Wheelwright NT (1985) Fruit size, gape width, and the diets of fruit-eating birds. Ecology 66: 808-818.
Appendix 1. Frugivorous bird species observed from May 1995 to April 1997 at the study site.

White-bellied Green Pigeon (Sphenurus sieboldii) Japanese Green Woodpecker (Picus awokera) Great Spotted Woodpecker (Dendrocopos major) White-backed Woodpecker (Dendrocopos leucotos) Japanese Pygmy Woodpecker (Dendrocopos kizuki) Brown-eared Bulbul (Hypsipetes amaurotis) Red-flanked Bluetail (Tarsiger cyanurus) Daurian Redstart (Phoenicurus auroreus) Scaly Thrush (Zoothera dauma) Japanese Thrush (Turdus cardis) Brown-headed Thrush (Turdus chrysolaus) Pale Thrush (Turdus pallidus) Eyebrowed Thrush (Turdus obscurus) Dusky Thrush (Turdus naumanni) Narcissus Flycatcher (Ficedula narcissina) Blue-and-white Flycatcher (Cyanoptila cyanomelana) Dark-sided Flycatcher (Muscicapa sibirica) Grey-streaked Flycatcher (Muscicapa griseisticta) Asian Brown Flycatcher (Muscicapa dauurica) Japanese White-eye (Zosterops japonicus) White-cheeked Starling (Sturnus cineraceus) Eurasian Jay (Garrulus glandarius) Carrion Crow (Corvus corone) Large-billed Crow (Corvus macrorhynchos) 


\section{Y. TAKANOSE and T. KAMITANI}

Appendix 2. Flowering and fruiting periods of fleshy-fruited plants observed at the study site.

\begin{tabular}{|c|c|c|c|c|c|}
\hline \multirow{2}{*}{ Species } & \multicolumn{2}{|c|}{ 1995-1996 } & \multicolumn{2}{|c|}{ 1996-1997 } & \multirow{2}{*}{$\begin{array}{r}\text { Fruiting } \\
\text { pattern }\end{array}$} \\
\hline & $\begin{array}{c}\text { Flowering } \\
\text { period }\end{array}$ & $\begin{array}{c}\text { Fruiting } \\
\text { period }\end{array}$ & $\begin{array}{c}\text { Flowering } \\
\text { period }\end{array}$ & $\begin{array}{c}\text { Fruiting } \\
\text { period }\end{array}$ & \\
\hline Morus australis & Apr.-May & Jun.-Aug. & May & Jun.-Jul. & $\mathrm{S}$ \\
\hline Broussonetia kazinoki & May & Jun.-Aug. & May -Jun. & Jul. & $\mathrm{S}$ \\
\hline Prunus verecunda & Apr. & Jun. & May & Jun.-Jul. & $\mathrm{S}$ \\
\hline P. jamasakura & Apr. & Jun.-Jul. & Apr.-May & Jun.-Jul. & $\mathrm{S}$ \\
\hline P. apetala ssp. pilosa & Apr. & May & Mar--Apr. & May -Jul. & $\mathrm{S}$ \\
\hline P. grayana & May & Jul.-Oct. & May & Aug.-Sep. & $\mathrm{S}$ \\
\hline Rubus crataegifolius & May & Jun.-Jul. & May -Jun. & Jun.-Jul. & $\mathrm{S}$ \\
\hline R. microphyllus & Apr.-May & Jun.-Jul. & May & Jun.-Jul. & $\mathrm{S}$ \\
\hline R. palmatus var. coptophyllus & Apr. & May -Jul. & Apr.-May & Jun.-Jul. & $\mathrm{S}$ \\
\hline R. phoenicolasius & Jun. & Jul.-Aug. & Jun. & Jul. & $\mathrm{S}$ \\
\hline R. parvifolius & Jun. & Jul. & Jun. & Jul. & $\mathrm{S}$ \\
\hline R. hirsutus & May & May -Jun. & May -Jun. & Jun. & $\mathrm{S}$ \\
\hline Coriaria japonica & Apr.-May & Jun.-Jul. & May & Jul. & $\mathrm{S}$ \\
\hline Elaeagnus multiflora var. hortensis & Apr.-May & Jun. & May & Jun. & $\mathrm{S}$ \\
\hline Swida controversa & May & Jul.-Oct. & May -Jun. & Aug. & $\mathrm{S}$ \\
\hline Acanthopanax spinosus & May & Jul.-Aug. & Jun. & Jul.-Aug. & $\mathrm{S}$ \\
\hline Sambucus racemosa $\mathrm{ssp}$. sieboldiana & Apr. & Jun.-Jul. & Apr.-May & Jun.--Jul. & $\mathrm{S}$ \\
\hline Viburnum plicatum f. glabrum & May & Jul.-Aug. & May -Jun. & Jul.-Aug. & $\mathrm{S}$ \\
\hline Celtis sinensis var. japonica & Apr.-May & Oct.-Jan. & May & Oct.-Dec. & $\mathrm{F}$ \\
\hline Magnolia salicifolia & $\ldots$ & Sep. & $\cdots$ & $\ldots$ & $\mathrm{F}$ \\
\hline Neolitsea sericea & $\cdots$ & Oct.-Feb. & Oct. & Oct.-Nov. & $\mathrm{F}$ \\
\hline Eurya japonica & $\ldots$ & Oct.-Jan. & Apr. & Sep.-Dec. & $\mathrm{F}$ \\
\hline Sorbus commixta & May & Oct.-Jan. & May & $\ldots$ & $\mathrm{F}$ \\
\hline S. alnifolia & May & Oct.-Feb. & $\ldots$ & $\ldots$ & $\mathrm{F}$ \\
\hline Pourthiaea villosa & May & Oct.-Feb. & May -Jun. & Nov.-Dec. & $\mathrm{F}$ \\
\hline Rosa multiflora & May -Jun. & Oct.-Mar. & Jun. & Oct.-Jan. & $\mathrm{F}$ \\
\hline Mallotus japonicus & Jun.-Jul. & Sep.-Jan. & Jul. & Sep.-Dec. & $\mathrm{F}$ \\
\hline Zanthoxylum piperitum & May & Sep.-Nov. & May & Sep.-Nov. & $\mathrm{F}$ \\
\hline Z. schinifolium & Aug. & Oct.-Jan. & Aug. & Oct.-Dec. & $\mathrm{F}$ \\
\hline Z. ailanthoides & Jul.-Aug. & Oct.-Jan. & Aug. & Oct.-Dec. & $\mathrm{F}$ \\
\hline Rhus trichocarpa & May & Aug.-Aug. & Jun. & Sep.-Dec. & $\mathrm{F}$ \\
\hline R. ambigua & May & Aug.-Jul. & May-Jun. & $\ldots$ & $\mathrm{F}$ \\
\hline R. javanica var. roxburghii & Aug.-Sep. & Oct.-Jul. & Aug. & Oct.-Feb. & $\mathrm{F}$ \\
\hline Meliosma myriantha & Jun. & Oct.-Nov. & $\ldots$ & $\ldots$ & $\mathrm{F}$ \\
\hline Ilex macropoda & $\ldots$ & Sep.-Dec. & $\ldots$ & $\ldots$ & $\mathrm{F}$ \\
\hline I. crenata var. paludosa & Jun. & Oct.-Dec. & Jun. & Oct. & $\mathrm{F}$ \\
\hline Euonymus sieboldianus & May -Jun. & Oct.-Nov. & Jun. & $\ldots$ & $\mathrm{F}$ \\
\hline E. alatus f. stiatus & May & Oct.-Jan. & May -Jun. & Oct.-Nov. & $\mathrm{F}$ \\
\hline E. oxyphyllus var. magnus & Apr.-May & Aug.-Oct. & May -Jun. & Sep. & $\mathrm{F}$ \\
\hline Vitis flexuosa & Jun. & Sep.-Dec. & Jun. & Sep.-Nov. & $\mathrm{F}$ \\
\hline Kalopanax pictus & Jul. & Sep.-Oct. & $\ldots$ & $\ldots$ & $\mathrm{F}$ \\
\hline Aralia elata & $\cdots$ & Oct. & Sep. & Oct.-Nov. & $\mathrm{F}$ \\
\hline Vaccinium oldhamii & $\ldots$ & Sep.-Dec. & Jun. & Sep.-Dec. & $\mathrm{F}$ \\
\hline Ardisia japonica & $\ldots$ & Oct.-Mar. & $\ldots$ & Oct.-Apr. & $\mathrm{F}$ \\
\hline Ligustrum tschonoskii & Jun. & Oct.-May & Jun.--Jul. & Oct.-Jan. & $\mathrm{F}$ \\
\hline Clerodendrum trichotomum & Aug. & Sep.-Nov. & Aug. & Sep.-Dec. & $\mathrm{F}$ \\
\hline Callicarpa japonica & Jun.-Jul. & Sep.-Jan. & Jul. & Oct.-Dec. & $\mathrm{F}$ \\
\hline Lonicera japonica & Jun. & Oct.-Feb. & Jun. & Oct.-Feb. & $\mathrm{F}$ \\
\hline Viburnum dilatatum & May -Jun. & Sep.-Feb. & May -Jun. & Sep.-Jan. & $\mathrm{F}$ \\
\hline V. wrightii & May & Sep.-Nov. & May & Sep.-Jan. & $\mathrm{F}$ \\
\hline Aucuba japonica var. borealis & Apr.-May & Nov.-May & Mar.-May & Nov.-May & SP \\
\hline
\end{tabular}

S, F and SP represent the summer-, fall- and spring-fruiting species, respectively. 